\title{
INTRODUÇÃO AOS COMENTÁRIOS SOBRE A PEÇA ÉDIPO REI I $I^{452}$
}

\author{
VIRGÍNIA LEONE BICUDO
}

Em 16 de maio último, a Sociedade Brasileira de Psicanálise e o seu Instituto participaram do debate público que se seguiu à representação da peça Édipo rei, de Sófocles, com Paulo Autran e dirigida por Flávio Rangel.

O debate, organizado pelo Instituto de Medicina, constou da apresentação de comentários sobre a peça ao público que lotou o teatro Maria Delia Costa. Os comentadores, psicanalistas e psiquiatras, procuraram destacar alguns aspectos da tragédia de Sófocles, com a finalidade de comunicar, em termos da razão, a mensagem do dramaturgo ateniense.

Arte e ciência, por meios diferentes, perseguem o mesmo objetivo de, pela busca da verdade, alcançar o bem-estar do homem. A arte se dirige diretamente às emoções, explorando a estesia e assim mobilizando a participação do público, através de intensa solicitação dos sentimentos e paixões, ligados a fantasias inconscientes. A ciência apela ao desejo inato e incoercível de saber sobre as motivações inconscientes.

A mente humana não está preparada para abarcar, no nível consciente, todo o conhecimento de sua própria natureza, sobretudo do inconsciente, no que se refere aos aspectos destrutivos de inveja, de voracidade e de morte, que ameaçam o sentido existencial.

A mensagem artística tem caminho mais livre para o interior da pessoa humana do que a mensagem do cientista, porque, dirigindo-se diretamente às emoções, permite à pessoa usufruir o prazer estético e assim transpor os níveis de resistência que acompanham a tomada de conhecimento consciente. Por isso, a reação do público ao debate científico difere daquela que assiste ao espetáculo artístico: inibição no primeiro caso e participação calorosa no segundo. É claro que a alta qualidade do espetáculo artístico dinamiza a participação emocional do público e que o debate científico, não convenientemente conduzido, não estimula a assistência à discussão.

Deve-se acentuar que a arte sempre alcança a promover o bem-estar espiritual do homem, tenha ou não o artista consciência de tal objetivo. A participação do cientista em debates da natureza do que foi promovido após a representação de Édipo rei faz-se necessária e com o sentido altamente construtivo de possibilitar a conscientização da mensagem comunicada através de recursos artísticos. Quando se trata de psicanalistas, sua contribuição ao debate de peças teatrais visa particularmente à tradução do conteúdo psicológico, social e cultural de fenômenos inconscientemente elaborados. A interpretação psicanalítica de uma obra de arte não altera seu valor como arte, da mesma forma que o conhecimento da fórmula química da água não diminui a emoção que resulta da contemplação de uma catarata espumejante ou de um lago tranqüilo. Assim pensando, transcreveremos a seguir os comentários sobre a peça Édipo rei, expressos no teatro pelos cientistas que participaram dos debates.

\section{Comentários}

I Virgínia Leone Bicudo 453

\footnotetext{
${ }^{452}$ Publicado originalmente na Revista Brasileira de Psicanálise, v. 1, n. 2, 1967.

${ }^{453}$ Diretora do Instituto de Psicanálise da Sociedade Brasileira de Psicanálise de São Paulo.
} 
Da tragédia de Édipo rei, Freud tirou a denominação do que entendemos por complexo de Édipo, isto é, que inconscientemente a criança está determinada a sentir amor por sua mãe e ódio por seu pai, como competidor.

Na peça de Sófocles, essa tendência psicológica aparece elaborada nas maldições, nas profecias e nos oráculos, o que conduz o povo a exigir punição para livrá-lo de males por crimes não punidos e Édipo rei à investigação para descobrir o criminoso responsável. $\mathrm{O}$ dramaturgo deixa claro que as necessidades instintivas e psicológicas são projetadas no mundo exterior e, então, elaboradas por processos sócio-culturais, definindo-se o modo "certo" de lidar com emoções, instintos, desejos e sentimentos através de reações que incluam a consideração pelos interesses do grupo. Se temos o intento de interpretar a peça Édipo rei, temos de considerar ambos os lados, isto é, o mundo interno dentro da mente e o mundo externo, em seus recursos para solver conflitos psíquicos e sociais.

Sabemos que a situação trágica de Édipo rei foi criada muito antes de seu nascimento, frente à qual ele era o resultado direto e não tendo nenhum meio de fugir ao seu destino préestabelecido. Este fato foi interpretado pelos gregos como desamparo do homem nas mãos dos deuses. Laio, apropriando-se do filho do amigo a ele confiado e seduzindo-o, ficou sob a ameaça da maldição, que o destinava a ser morto pelo próprio filho. Para evitar a maldição, Laio permaneceu solteiro por anos. Casando-se com Jocasta, a ela confiou o seu segredo e quando tiveram o filho ambos concordaram em abandoná-lo, com os pés atados. Assim começa a tragédia de Édipo, demonstrando que aquilo que está inscrito na mente tem que ser atuado fora. A peça de Sófocles nos dá evidência do poder da mente inconsciente sobre o conscientemente estabelecido.

Quais foram as determinantes inconscientes de Laio, Jocasta e Édipo? Laio e Jocasta, agindo sob o medo da maldição, em realidade agiram em função do medo inconsciente de pais perante os filhos, vendo-os como ameaça ao status de "adultos perfeitos". Por outro lado, é também verdade inconsciente que a criança, psicologicamente, não suporta a sua dependência de adultos vistos ou sentidos como perfeitos.

Abandonando ou matando seu filho, Laio e Jocasta esperavam livrar-se da maldição, porém os acontecimentos conseqüentes provaram que tal "acting out" de desejos inconscientes não é solução. Jocasta sentiu-se tão culpada que se suicidou. Édipo escolheu seu castigo cegando-se e destituindo-se de todos os direitos de cidadão tebano. A cegueira, conforme ele mesmo declarou, foi o castigo que escolheu pela culpa de não ter sido capaz de reconhecer seus pais reais, quando os encontrou. Sófocles sugere que Édipo possuía o conhecimento inconsciente para reconhecer os pais, mas os ignorou por ser-lhe intolerável estar consciente de seus impulsos parricidas e incestuosos. Seus olhos falharam quando mais deles necessitou, lamentava Édipo, e, portanto, tinha de puni-los, assim cumprindo, em nosso entender, a lei moral que cobra na base de olho por olho e dente por dente. Esse aspecto nos leva ao conceito de reparação como o mecanismo psíquico e social mais altamente desenvolvido para lidar com a destrutividade instintiva.

Jocasta, como a mãe que se tornara tão terrível para si própria como para o filho, matou-se na esperança de que seu filho pudesse viver, não tendo que enfrentá-la contínuadamente como a lembrança de seu crime. Ela fracassou no intento de impedi-lo que continuasse a pesquisar sobre a identidade do criminoso, num momento em que ela já havia adquirido o conhecimento consciente de toda a tragédia. Matou-se acreditando que, com esse sacrifício, a todos absolveria, livrando o povo tebano da punição.

Quanto mais desenvolvidas sejam a cultura e a organização social, tanto menos haverá necessidade de atuar matando parcial ou totalmente, como um meio de falsa reparação a danos causados a terceiros. É verdade que entre pais e filhos existem sentimentos inconscientes e recíprocos de incesto e de agressividade hostil. Para modificar esses 
sentimentos devemos simultaneamente desenvolver o conhecimento consciente da parte destrutiva da natureza humana e a capacidade de amor e de real reparação.

A cegueira de Édipo rei não foi um ato de verdadeira reparação (e muito menos o suicídio de Jocasta) porque, cego, ele se tornou menos efetivo em seu desejo de reparar seus crimes. No sofrimento de solidão da cegueira não há reparação, porém isso o aliviava de culpa pela crença pessoal mantida nos significados culturais de que a expiação pelo crime absolve o criminoso e a sociedade.

Na tragédia de Édipo rei, Sófocles iluminou o conflito permanente entre dois instintos fundamentais - o instinto de vida e o instinto de morte. Na peça, o instinto de morte é por cinco vezes manifestado através de acting out. A primeira vez, quando Laio e Jocasta abandonam o filho com três dias de vida; a segunda, quando Édipo mata o pai; a terceira, quando Édipo se casa com Jocasta; a quarta vez, quando Jocasta se suicida; e a quinta vez, quando Édipo cega os próprios olhos com os filetes dos broches de sua mãe-espesa. Por outro lado, o instinto de vida é mostrado em ação, superando o instinto de morte nas seguintes situações: na preservação da vida da criança abandonada, pelos humildes servo e pastor; na adoção da criança pelo rei e sua mulher; na busca da verdade como desígnio irresistível e incessante de Édipo; na punição que Édipo se impõe, poupando sua vida para promover reparação, e em seu interesse em livrar o povo de castigos. Os crimes de filicídio, parricídio e incesto são intoleráveis para o indivíduo e para a sociedade, pois são tão desintegradores para o indivíduo, quanto destroem a estrutura e os significados culturais de qualquer sociedade.

\section{Durval Marcondes ${ }^{454}$}

O tema oficial da recente Jornada Brasileira de Psicanálise, nela amplamente discutido, foi o acting out, palavra inglesa para cuja expressão em português costumo usar o vocábulo "atuação". De modo esquemático, a atuação consiste no seguinte: quando, no decurso do tratamento psicanalítico, se torna iminente a tomada de contato com certo material inconsciente, ela é evitada por meio de uma descarga pela ação, que vem substituir-se à apreensão racional. Um exemplo grosseiro, tendo apenas a finalidade de tornar o assunto mais claro, seria este: numa psicanálise, o paciente está prestes a trazer à consciência impulsos agressivos contra o pai, com raízes em seu passado infantil. Em vez de fazê-lo, passa a agredir verbalmente o analista. Ou então, fora da situação analítica, passa a brigar com o patrão, o professor etc. Assim, o indivíduo age em vez de pensar.

$\mathrm{Na}$ impossibilidade de abordar os imensos e variados aspectos desse verdadeiro universo psicológico que é Édipo rei, seria interessante apontar um deles, que ressalta na conduta trágica do personagem principal e que é constituído pela atuação. O assunto acaba, aliás, de ser magnificamente tratado por Arnaldo e Matilde Rascovsky em seu trabalho ainda inédito, escrito para ser apresentado ao XXV Congresso Psicanalítico Internacional e intitulado "Genesis del Acting out y de la Conducta Psicopática en Édipo".

Através dos variados acidentes de sua história, Édipo nos revela dois elementos básicos e contraditórios de sua atitude, que são os desejos de saber e de ignorar, os quais encontram repetidamente uma satisfação por meio de uma variada atividade impulsiva.

A peça Édipo rei resume-se num constante diálogo de Édipo consigo mesmo, no conflito de duas partes de sua personalidade, opostas entre si, as quais, neste ou naquele instante, são representadas pelo próprio Édipo ou são projetadas em outras personagens do drama.

Já no início do desenvolvimento da peça e conforme nos faz ver G. Róheim em seu trabalho "Teiresias and other Seers", Édipo e Tirésias representam dois aspectos da mesma pessoa, expressos no diálogo entre a repressão (Édipo) e a volta do reprimido (Tirésias). Mais

\footnotetext{
${ }^{454}$ Presidente da Sociedade Brasileira de Psicanálise de São Paulo.
} 
adiante, o diálogo se dá entre Édipo e Jocasta. Como apontou S. Ferenczi em seu trabalho Symbolische Darstellung des Lust und Realitatsprinzips im Oedipus Mythps, Édipo e Jocasta representam respectivamente o princípio da realidade, na busca infatigável da resposta acertada, e o princípio do prazer, que não procura a verdade objetiva mas visa apenas alcançar a satisfação direta, poupando o ego de qualquer sofrimento. Na desvalorização da pesquisa esclarecedora, Jocasta assume o papel de agente inspirador da atuação, quando desmerece a significação da verdade e incita à comodidade da situação presente.

Nas atitudes de Édipo, a atuação se mostra a todo instante, utilizando os mecanismos de onipotência, projeção, idealização etc. Pela onipotência, Édipo salva-se da destruição, mata o pai e desposa a mãe. Pela projeção, acusa Tirésias e Creonte, e pretende puni-los. Pela idealização, exalta os pais nas pessoas de Pólibo e Mérope. E assim por diante.

Entretanto, a mais significativa forma de atuação na conduta de Édipo é a sua disputa com a esfinge. A vitória (ou pseudo-vitória) sobre a esfinge traduz a condensação de duas ações diferentes, mas contidas no mesmo impulso: o extermínio do pai e a posse da mãe. Como nos mostrou T. Reik (Oedipus und die Sphinx), a esfinge representa, ao mesmo tempo, as figuras de Laio e de Jocasta. Na luta de Édipo com a esfinge, o assassínio e a união sexual são sincronizados no mesmo ato. Esse acontecimento envolve uma reação à cena primária, que é a cópula dos pais como é pressentida ou fantasiada pela criança. Aliás, a esfinge é vista por vários psicanalistas, entre os quais G. Róheim (The Riddle of the Sphinx), como representando os pais unidos na cena primária (figura combinada dos pais).

A descoberta de sua inclinação parricida e incestuosa não afastou Édipo de sua tendência à atuação. Privando-se da vista, insiste em continuar ignorante e reincide, através de um agir que constitui, ao mesmo tempo, uma fuga e uma autopunição, na recusa de defrontarse com a realidade assustadora e aceitá-la em todas as suas terríveis conseqüências.

\section{Darcy M. Uchôo $a^{455}$}

Como é sabido, foi buscar Sófocles, como aliás outros grandes trágicos, material e inspiração para suas obras no inesgotável manancial das lendas gregas (o ciclo tebano, por exemplo). Posto outros autores tenham-se ocupado do mito edipiano, é fora de dúvida que a obra de Sófocles, Rei Édipo, destacou-se como a mais perfeita quanto à força da inspiração e à maestria da técnica. É evidente que o talento ou gênio de um autor se manifesta na excelência e autenticidade de sua mensagem, isto é, na forma pela qual, algo inefàvelmente, comunica à audiência conteúdos cada vez mais universais da alma humana. Ressaltam dois grandes problemas de ordem psicológico-artística: o da inspiração criadora do artista e o da essência do prazer estético do espectador. Conhecemos pelos trabalhos de Freud, Sachs, Jones, Rickman, Sharpe e outros, o papel da realidade interior, isto é, das recordações da infância, da fantasia, do daydreaming, do simbolismo, da sublimação no inspirar e criar a obra de arte, mas força é reconhecer a existência de muitas incógnitas que ainda continuam a desafiar o trabalho de investigação psicológica nesse tão importante quão completo campo da personalidade humana. A tragédia Rei Édipo refere-se a temas profundos, talvez mesmo universais, da alma humana. Temas de grande lastro afetivo alusivos a conflitos básicos radicados a planos os mais profundos da personalidade. Sófocles tenta demonstrar a impotência do homem diante dos deuses, dirigentes dos destinos humanos. Édipo vai sendo colocado em situações cada vez mais trágicas: tem de esclarecer terrível crime que pesa sobre Tebas, punindo-a com a peste, a morte e a desolação. Volta Creonte com a mensagem-ordem do oráculo: o culpado tem de ser descoberto e a morte de Laios vingada, remida, reparada. Não hesita o altivo, orgulhoso e inteligente rei que, ao vencer a esfinge, se tornou, não apenas

\footnotetext{
${ }^{455}$ Membro efetivo e psicanalista didata da Sociedade Brasileira de Psicanálise de São Paulo.
} 
o rei de Tebas, mas o esposo da rainha Jocasta. Inicia com entusiasmo e obstinação a busca do culpado, ainda de todo inconsciente de que é ele próprio o objeto buscado.

A audiência, todavia, estremece ao sentir e intuir a terrível verdade comunicada por Tirésias e agressivamente negada por Édipo. Este nega e logo projeta a culpa sobre o adivinho, que estaria a serviço de Creonte em conspiração para a usurpação do trono.

Édipo se envolve mais e mais na trama da qual jamais sairia e, quanto mais procura, mais vai-se encontrando. Mas a angústia, agora contaminando Jocasta, exerce, paradoxalmente, diabólica fascinação sobre o infeliz rei. Busca, obstina-se, mas defende-se cada vez mais ineficientemente, pois as defesas vão-se abatendo à medida que se vai desvelando a verdade, toda a verdade. O espectador agora já sabe o que ocorreu realmente: a profecia realizou-se, pois Édipo assassinou realmente seu pai e desposou sua mãe, a infeliz rainha agora também fatal e tragicamente enleada na trama fatídica. Ambos os protagonistas sofrem terrivelmente de culpas, a princípio inconscientes, mas agora caminhando quase vertiginosamente para a zona da consciência clara. Introjeta e projetivamente identifica-se com eles o espectador, também já envolvido e comprometido no campo conflituoso organizado pelo gênio de Sófocles. Ataques ao pai no assassínio de Laios, impulsos incestuosos realizados no leito nupcial de Jocasta: agressão e morte de um lado, amor incestuoso de outro, eis as situações básicas que mobilizam na audiência intensos e contraditórios sentimentos. A culpa persecutória evolve lenta mas fatalmente para a culpa depressiva ao falharem a divisão, projeção e negação. Revelam-se inúteis os esforços de Jocasta por salvar Édipo salvando-se a si mesma, pois Édipo é arrastado por imperativos instintivo-emocionais e pela pressão da culpa persecutória e já não pode deter-se. Os deuses ordenaram e os fados têm de ser cumpridos... da mesma forma que tensões emocionais incoercíveis vão abrindo caminho desde o inconsciente mais profundo rumo à sua fatal exteriorização. O campo inter-relacional audiência-protagonistas se fecha em círculo de ferro, mobilizando emoções as mais básicas e profundas. Há toda uma catarse liberadora através de terríveis sofrimentos que se prenunciam, anunciam e pouco a pouco se vão concretizando... O crime foi cometido, há culpas a serem resgatadas, há agravos a serem reparados; há crime e necessidade de punição, há isso e mais que isso nessa poderosa tragédia sofocliana.

Jocasta não pôde enfrentar a terrível realidade ao falharem seus esforços de negação. Sentiu com toda força o horror do crime inconscientemente cometido ao desposar o próprio filho, dando à luz filhos indelevelmente marcados pelo incesto. Édipo tenta desesperadamente a reparação, autopunindo-se ao mutilar o seu próprio corpo. Fere ou arranca seus próprios olhos para que não continuem vendo, deslocamento provável a partir dos órgãos genitais usados no hediondo incesto. Autopunição a serviço da reparação... tema que preocupou Sófocles, como demonstra sua continuação e posterior elaboração na última tragédia escrita quando já nonagenário: Édipo em Colona.

Tragédia esta rica de conteúdo psicológico, provavelmente de sentido universal, que tanto agita a alma humana, manipulada pelo gênio de Sófocles e que comunica dramática e tragicamente mensagens vindas dos planos mais profundos do inconsciente individual e coletivo com seus complexos e arquétipos. O gênio de Sófocles afirmou-se aqui na maestria com que soube transformar uma rica e dinâmica fenomenologia psicopatológica numa obraprima do teatro trágico universal.

\section{Margareth J. Gui ${ }^{456}$}

Esta é a tragédia de um homem forte tentando reconciliar a felicidade dele com o bem da comunidade, de um soi disant homem honesto quebrado por um fado-sorte inexorável. Se tivesse sido um fraco, lamentando as exigências dos deuses, protestando inocência, recusando

\footnotetext{
${ }^{456}$ Membro efetivo e analista didata da Sociedade Brasileira de Psicanálise de São Paulo.
} 
aceitar responsabilidade pelas conseqüências dos seus atos ou tentando escapar delas fechando os dois olhos, como sua mulher sugeriu; se tivesse desafiado as autoridades perseguindo sua própria felicidade, nós não teríamos sofrido com ele o que, estou certo, ocorreu a todos nós, nem teríamos sentido a catarse emocional que experimentamos através da identificação com ele nas suas transgressões, no seu reconhecimento corajoso, passo a passo, de sua culpa e de seu remorso na agonia.

O fado-destino como os gregos o compreenderam queria dizer a vontade inescrutável e arbitrária dos deuses, muitas vezes decretado antes de o indivíduo nascer e contra o qual ele não tinha recursos. Freud ao contrário tem nos ensinado que nosso destino é decidido interiormente e é decretado, podemos dizer, por nosso caráter, e este por sua vez é resultado da direção que nós temos dado aos nossos instintos e impulsos inatos durante nosso desenvolvimento precoce e da disciplina que nós temos podido exercer sobre eles. Para nós o destino é inflexível como era para os gregos; somente que agora, reconhecendo a sua verdadeira origem nos demônios e nos deuses dentro de nós (modificados ou exagerados, por dons pessoais ou por circunstâncias ambientais), temos mais recursos.

A proibição do parricídio e do incesto, reconhecida intuitivamente como necessária para a construção de uma sociedade, chegou cedo na evolução do homem, muito antes mesmo do que na restrição dos impulsos, contra os quais atuavam as leis que Moisés nos trouxe do alto da montanha. Essa proibição e as conseqüências destrutivas de suas transgressões são elaboradas nos mitos e folclores de todos os povos antigos, não só dos gregos.

Mas os impulsos ficam indestrutíveis e a prova disto vemos todos os dias em nossos sonhos e no sussurro inocente de nossas crianças. Sobre o sofá do analista nós seguimos a pista e os achamos, como o fez Édipo nesta peça, através das defesas de projeção, negação e racionalização até que eles, nossos pacientes, por fim, dado o peso cumulativo das vozes interiores do "insight" e sensação impossível de ignorar, as quais na peça reconhecemos como as palavras postas nas bocas das outras personagens, procuram, uma outra vez, como Édipo, o alívio pelo reconhecimento de culpa, pelo remorso e pela restituição.

Sófocles mesmo, na seqüência desta peça, chamada Édipo em Colona, reconhece no final que a procura da mãe é eterna, e que mesmo depois de seus muitos anos de sofrimento e expiação, Édipo ainda continuava procurando-a.

Por esse motivo, permite ao seu herói terminar o seu penoso caminho, numa volta simbólica e gloriosa à sua mãe, mas agora com a permissão do pai e da sociedade, uma vez que toma a forma dum sepultamento num lugar sagrado não visto por outros olhos a não ser os do rei.

Para nossos pacientes nós não desejamos nem a solução de Édipo rei, que é a castração e a deportação, nem a de Édipo em Colona, que é regressiva. Ao contrário, esperamos que eles possam achar os dois pais unidos na pessoa que escolheram como marido ou esposa, num casamento saudável e feliz.

\section{Isaias H. Melsohn ${ }^{457}$}

Diante de Édipo, somos tentados a discutir o mito, a obra de arte e a interpretação psicanalítica.

Como é sabido, o mito de Édipo representa a projeção cultural, em tempos primevos da cultura helênica, de uma situação humana cuja universalidade deu origem a uma das concepções básicas de todo o edifício teórico da psicanálise.

Hesíodo e Homero, "que deram aos deuses gregos os seus nomes", relatam como, à época dos reis lendários, à época de Pelops, Cadmo, Teseu, foram instalados na Hélade os primeiros núcleos de civilização. Refere a lenda como aqueles primeiros Estados-reinos foram

\footnotetext{
${ }^{457}$ Membro efetivo e analista didata da Sociedade Brasileira de Psicanálise de São Paulo.
} 
fundados por estrangeiros; assim, Atenas, por Cécrops, egípcio. Danaos, também do Egito, se estabelece em Argos e dele descendem Danae e Perseu. Cadmo, de origem fenícia, ancestral de Édipo e fundador de Tebas, teria trazido consigo as letras de escritura. Pelops, da Frigia, funda, em Micenas, a casa real que seria berço de Atreus e dos Atreidas, Agamenon e Menelau. Nos seus primórdios, a rapina, o parricídio, o matricídio, a promiscuidade marcam com um lastro de crimes hediondos as relações pessoais. Atreus, genitor de Agamenon, oferece em banquete os corpos dos filhos do irmão em vingança contra ele. Agamenon imola a própria filha. Em represália, Clitemnestra o assassina e Orestes perpetua a sanha sanguinária que pesa como maldição sobre sua estirpe, tirando a vida à própria mãe. De resto, os próprios deuses mais antigos repetiam, em seu habitat transcendente, as andanças e os crimes dos homens. Oceanos elimina os filhos até que um deles, Cronos, salvo por Geia, sua mãe, o esquarteja; para não ser sacrificado pelos seus descendentes, ele os devora. Geia procria em relações incestuosas com os próprios filhos.

É com o advento de Zeus que nova ordem moral haveria de ser imposta no Olimpo. $\mathrm{Na}$ terra dos homens, Orestes - na interpretação de Esquilo - defendido por Apolo, o luminoso deus do sol, e libertado pelo voto de Atena, não tem mais de pagar com o tributo do próprio sangue a voragem de crimes perpetrados por seus ancestrais e por ele mesmo. Com Édipo assiste-se ao despontar de nova forma de consciência. A esfinge, cujo mistério ele decifra, representava o misto de ser humano e animal, legado do Egito, a caracterizar a imersão do espírito na natureza e sua relativa subordinação à animalidade. Seu segredo encerra a natureza humana; quando o homem adquire a consciência de sua espiritualidade, a noção do seu ser, de sua totalidade como objeto, ele supera os níveis inferiores, que ainda o mantêm preso à animalidade, com a noção de que o bem e o mal radicam em si próprio. Por isto a esfinge, a antiga forma de espiritualidade humana, é precipitada do rochedo para o fundo do mar: o ódio, que antes imperava abertamente, passa a ser dominado e reprimido, e se alberga nas profundezas da alma. No entanto, o mesmo homem, o rei, aquele que descobriu um dos mistérios do espírito, sucumbe ante o império de outras forças misteriosas que o impelem a destinos inexoráveis. Mas ele impõe a si próprio a exigência de tudo desvendar, e sua moralidade se opõe ao destino obscuro: há que pagar o crime e, com o exemplo da própria vida, bani-lo do convívio humano.

Aqueles tempos, há cerca de 3.500 anos, eram, também, os tempos em que Moisés guiava seu povo através do deserto em direção à Terra Prometida e lhe outorgava os divinos mandamentos. Esse mesmo povo que, apenas ausente o guia e legislador, retrocede para o culto do bezerro de ouro e sucumbe à promiscuidade e aos costumes primitivos.

Esfinge, bezerro de ouro: criações míticas derivadas de formas de vida a serem superadas, projeções espirituais de homens cuja individualidade e consciência social iam sendo reconstruídas, culminando nos deuses pessoais do Olimpo e no Deus de Moisés. Para a consciência do povo egípcio, seu próprio espírito se apresentava como envolto em mistério; é o que se pode ver na célebre inscrição do santuário da deusa Naíth, em Sais: "Eu sou o que é, foi e será; jamais ninguém levantará o meu véu". Mas o fruto que deu à luz foi Apolo, o deus do sol, expressão da clarividência espiritual nos primórdios da civilização grega. $\mathrm{Na}$ divindade egípcia, a verdade se esconde; a solução é o Apolo grego (Hegel), e sua sentença "Homem, conhece-te a ti próprio" - marcaria, para os séculos seguintes, as vicissitudes desse extraordinário impulso cultural que foi o gênio grego.

No seu contexto social, Édipo representa, assim, um dos momentos altos de amadurecimento da espiritualidade porque, aceitando, por fim, sua culpa, assume o ônus e a responsabilidade pela indignidade da ação ominosa, ainda que involuntária e inconsciente. Bem diferente é o sentimento de Orestes; ele recua aterrorizado ante as imprecações das fúrias e os suplícios que o aguardam no Hades, mas não está propriamente arrependido do crime que conscientemente cometeu. É por isto que teme o castigo e invoca o auxílio dos deuses para absolvê-lo. Orestes, em conflito com forças externas, vive angústias paranóides. Édipo está 
em conflito consigo próprio. O crime e a expiação de Édipo representam uma ascensão moral, como condição necessária para edificação de bases mais sólidas da vida comunitária.

Tudo isto, porém, nos mantém ao nível da interpretação discursiva do mito. Outra é sua função na sociedade primitiva. Não exprime meramente a emergência de fantasias decorrentes da elaboração de conflitos humanos, mas, dado o seu caráter afetivo e de representação imaginário-plástica, se constituiu no instrumento social para a articulação de emoções e preservação de experiências adquiridas. Desta forma o mito configura a experiência emotiva que ordena o comportamento prático, o sentimento e a ação moral.

Com isso nos aproximamos, também, do universo estético. $\mathrm{O}$ caráter peculiar à obra de arte não é o tema que nela está elaborado, mas a forma simbólica que lhe é própria. Para Freud e, em geral, para os primeiros teóricos do movimento psicanalítico, o mito de Édipo, a tragédia de Sófocles e a concepção psicanalítica do complexo de Édipo e dos seus reflexos na conduta e na criação espiritual exprimem idêntico "conteúdo", vazado em formulações diversas, em "linguagens" distintas. Mais que isso: a concepção psicanalítica, que dá expressão lógico-gramatical aos processos emocionais e representativos subjacentes ao mito e à tragédia, pretende constituir a verdade e o real que se escondem por trás dessas formas de criação.

Afirmava Freud que lhe era necessário interpretar e compreender o sentido e o "conteúdo" da obra de arte para gozar plenamente a emoção estética ("O Moisés de Miguel Ângelo" - 1914). Razão por que seria válida a tentativa de formular em palavras as "intenções do artista", que, através da obra, permite "reproduzir no espectador a situação afetiva, a constelação psíquica, que desencadeou o impulso criador" (op. cit.). Dizia: "Onde não consigo alcançar tal compreensão, como, por exemplo, na música, sou quase incapaz de prazer algum" (op. cit.). Entendo, porém, que essa necessidade de se apoiar em interpretações discursivas da música resulta antes de certa claudicação da sensibilidade de Freud às formas musicais, como, de resto, de todos aqueles que buscam tais significados na obra musical.

De toda forma, Freud sentia-se mais cativado pelo tema psicológico do que pelas qualidades que atestam da excelência da criação (op. cit.); a despeito disto chamou-lhe "a atenção o fato, aparentemente paradoxal, de que precisamente algumas das mais grandiosas ou mais imponentes obras de arte permanecem impenetráveis ao nosso entendimento. Admiramo-las, sentimo-nos dominados por elas, porém não poderíamos exprimir o que representam para nós" (op. cit.).

Hanna Segal, em artigo escrito em 1952, abandona e critica as tentativas de compreensão da obra artística através da análise do tema.

Em verdade, porém, não há nada de paradoxal no fato de que a obra de arte seja impenetrável ao entendimento. Porque o entendimento é o discurso, é a organização lógicogramatical, é o universo dos objetos da experiência perceptiva e realista do adulto contemporâneo. Ao passo que a "realidade" da obra de arte é outra; arte e mito não são formas diversas de um mesmo conteúdo que possa ser expresso pela proposição gramatical. Toda forma simbólica veicula seu conteúdo próprio. A arte cria um universo de emoções e de valores veiculados por via não discursiva; eis seu conteúdo que, como tal, está totalmente realizado em sua forma. Pois somente essa forma identifica, diferencia e desenvolve seu próprio conteúdo inerente: o sentimento que se revela como tal. Arte e mito são formas de concepção que permitem articular e comunicar diretamente sentimentos, não concepções que apenas se referem a eles; são modos fenomenais próprios, específicos, nos quais a consciência põe para si um dos seus modos próprios e específicos de ser: o sentimento representado em sua intimidade inefável, não o sentimento denotado pela palavra do discurso. É esse o mundo que a tragédia revela.

No entanto, a psicanálise, ciência, pode concorrer para o deslinde da trama de motivações, impulsos e afetos que se assenhoreiam dos personagens, pode esmiuçar, enriquecendo com novas significações, os caracteres trágicos. Incluída no contexto da análise 
artística, descobre novas dimensões das forças psicológicas e sociais em jogo. Mas, em si, ela revela, como toda análise, inclusive a estética, o mundo da ação humana, da opção e do destino, do trágico e do sublime, em nível do discurso e do entendimento. Isso não impediu, por outro lado, que as incursões de Freud no plano da análise literária se constituíssem em ensaios críticos magistrais, como, por exemplo, "O Delírio e os Sonhos" (1907) estudo da novela "Gradiva" de W. Jensen, de valor literário superior ao da própria novela, no dizer de críticos que conhecem ambas as obras.

A tragédia, portanto, revela o mundo humano como concepção da própria emoção, como emoção vivida simbolicamente; capaz de galvanizar a alma, permite, simultaneamente, estabelecer a imprescindível distância para a contemplação da paixão. Ela conduz, num átimo do tempo, à apreensão do sentido da totalidade da existência, porque configura as emoções que a caracterizam de modo cabal e pleno, fixa seus momentos essenciais, justamente aqueles prenhes de totalidades de significação, e os condensa em ação momentânea, num lampejo súbito a clarear perspectivas que se comunicam de imediato à intuição. Mas esse mundo emocional outro não é senão o de todo ser humano; e aquilo que a tragédia permite articular vividamente são os sentimentos que apenas se insinuam palidamente, na experiência prosaica da vida habitual. $\mathrm{O}$ espectador, imerso num mundo que, por verdadeiro encantamento, brota diante dos seus olhos, sabe que vive no imaginário; mas, precisamente, esse saber do imaginário, que condiciona a possibilidade de contemplar a própria emoção, é que dá a dimensão da magia inerente à obra de arte.

A emoção estética adquire, assim, significação singular. Ela se apóia no sensível, no desejo, no impulso, e é, ao mesmo tempo, forma de consciência. Talvez por isto mesmo se constitua na forma mais harmoniosa da experiência humana, aquela que concilia desejo e pensamento, subjetivo e objetivo, sentimento e pensamento, indivíduo e grupo. Foi assim considerada por grandes figuras como Schelling, Hegel e Schiller. O primeiro via na "função estética" a forma suprema do desenvolvimento do $\mathrm{Eu}$, aquela em que "a atividade inconsciente e consciente do Eu permite a manifestação plena de suas potencialidades e estabelece a unidade entre a vontade (impulso) e o pensamento teórico". Schiller propunha, como ideal da mais alta cultura, a educação estética, que enobrece o instinto e permite o acesso à vida moral.

A emoção estética, como captação simbólica da experiência emotiva, nos reconduz à psicanálise, não mais como teoria, mas como atividade, na lide viva com o subjetivo. Em sua prática como terapeuta, o analista não procede discursivamente, mas tenta apreender o "aqui e agora" da emoção emergente. O "material", o relato, a ação, não são considerados como forma verbal que denota acontecimentos, porém como construção simbólica que veicula sentimentos; não é o sentido "objetivo" do relato que norteia o pensamento, mas a captação intuitiva de significações dos elementos no contexto da experiência total do momento. $\mathrm{O}$ contexto, a totalidade, que empresta sentido aos elementos, se estrutura como forma simbólica não discursiva cujos conteúdos não são "realidades objetivas", mas emoções e significações subjetivas. Quando, através da interpretação, o paciente apreende o significado de sua emoção, quando sente que pessoas e objetos são organizados pelos seus próprios impulsos, ele adquire nova consciência da realidade: o mundo exterior, que ele acreditava ser o determinante, passa a ser visto como o resultado de sua ação. Como na emoção estética, contempla sentimentos que reconhece, agora, como seus. O progresso interior resulta dessa contemplação das emoções; é ela que marca a transformação do paciente que, de objeto a sabor de impulsos, passa a sujeito consciente de sua ação.

\section{Luiz Miller de Paiva ${ }^{458}$}

\footnotetext{
${ }^{458}$ Instituto de Psicanálise da Sociedade Brasileira de Psicanálise de São Paulo.
} 
Tentaremos demonstrar que a peça Édipo rei de Sófocles sugere como as agressividades herdadas, representadas pelos conflitos inconscientes dos pais, podem afetar um filho, a começar em sua vida intra-uterina, como, também, reger, não só o seu destino, mas o de uma família toda.

No prólogo, Édipo diz: "Meus filhos, descendência nova de Cadmo". Cadmo era um herói lendário que matara um dragão e, semeando os seus dentes, nasceram guerreiros; representação mitológica da herança hostil que pode marcar o destino dos homens por gerar sentimentos culposos. Édipo rei é pois uma tragédia baseada no alucinante problema de se enfrentar o destino cuja força muitos respeitam porque percebem a sua existência. $\mathrm{O}$ inexorável destino (o ananke dos gregos) é para todo psicanalista um estimulante desafio. Sartre sucumbiu a ele em "Les jeux sont faits". Se o destino de Édipo comove é porque afeta, de maneira profunda, muita gente. Estava reservado ao ser humano dirigir à própria mãe o primeiro impulso sexual e ao pai o primeiro sentimento de ódio destrutivo (inveja), daí Édipo representar a realização das fantasias infantis. Estas fantasias ficam reprimidas, tal como em Édipo rei. O pai proibidor e vingativo irá reger o comportamento futuro do adulto e se converterá no núcleo da moral e dos costumes.

O nível expressivo é regido pelo princípio de identidade de Von Domarus, utilizado nos pensamentos peleológicos dos esquizofrênicos, e, tal como os mitos, fantasias, sonhos e jogos são criações necessárias para uma atuação substitutiva. As versões contraditórias de um mesmo fato não se invalidam mutuamente para o psicanalista, tal como no conto japonês "Rashomon"; a verdade é mais complexa que a versão que se pode dar. Édipo não é só o amor de um filho para com a mãe, é mais do que isso, é como dizem Deveroux e Abadi: uma defesa contra a sedução homossexual do pai para com o filho. Vejamos os argumentos a favor desta tese: 1. Há uma versão que Édipo matara seu pai no curso de uma disputa surgida pela rivalidade amorosa por sua paixão homossexual por Crisipo (citada em "As fenícias" de Eurípedes); 2. O pai de Édipo, Laio, casado com Jocasta, não tendo filho, foi consultar secretamente o oráculo. Esse informa que a esterilidade era uma bênção e Laio, então, deixou de ter intimidades sexuais com a esposa. Jocasta, por represália, embebedou-o e concebeu Édipo. Laio, logo após o nascimento de Édipo, arranca-o dos braços da mãe, une os seus pezinhos com um gancho (oidypus - Pés inchados) e manda o escravo levá-lo ao monte Citerão.

Tanto na mulher como no homem, a nossa experiência psicanalítica tem mostrado que a esterilidade representa um medo que o filho faça com a mãe ou com o pai o que eles desejariam ter feito, em suas fantasias infantis: destruir a própria mãe ou o próprio pai. $\mathrm{O}$ motivo estaria na inveja que haviam tido dos pais. Laio, por conflito com o próprio pai, tornou-se homossexual, pois o homossexual, não se identificando com o pai (pai ausente ou demasiadamente severo não permite a identificação), foi buscar nos outros homens aquilo que não recebera do pai: a segurança. O pai de Édipo, conta a mitologia, roubara o jovem Crisipo, não só por amor, mas pela agressão, pois na Grécia não era condenada a homossexualidade. Em um sentido psicanalítico, o pai que rouba o filho da mãe, o faz por inveja de não ser igual à mulher. Aliás, os nossos indígenas praticam a "couvade", isto é, por ocasião do nascimento de um filho ficam na rede recebendo as visitas e a esposa vai trabalhar... Laio, arrancando Édipo dos braços da mãe, estava, inconscientemente, roubando-o da mãe, salvando-o da agressão da mãe-fálica e, também, pelo medo de seduzi-lo; em um sentido profundo, não queria matá-lo. É a onipotência na procriação; não aceita a superioridade da mulher. Esta inveja é porque a mulher-mãe recebe o homem-pai e não é destruída por ele. A cena primária, imaginada pela criança como algo destruidor e sádico, persegue o indivíduo até a sua idade adulta, causando distúrbios sexuais, infelicidades conjugais etc. Apesar de admirá-la, a mãe é muito temida. O episódio da esfinge na entrada de Tebas representava um castigo de alguma culpa incógnita. Era a culpa de Jocasta, por infanticídio, ódio de mãe contra o filho, por ódio ao homem como expressão da luta dos sexos, enfim, culpa do incesto com o próprio filho 
(segundo Pausania, Oidypais significaria mar inchado, esbravecido; sendo ele salvo por Méropes, no mar dentro de um cofre). Jocasta sempre preferia negar a verdade, desconhecê-la e viver em cômoda ficção.

A adoção de uma criança significa receber um filho sem pecado, isto é, sem incesto e sem inveja: é o renascimento. Édipo não concebe união sadia dos pais; castiga-se pela culpa do parricídio, arrancando os olhos no desejo de não mais ver o "insight" (verdadeira castração) e, finalmente, se agride, agredindo a mãe (aquela que me deu a luz toma a luz). É o fracasso diante do DESTINO.

A técnica psicanalítica, na qual se pretende ter uma melhor visão interior e assim melhor "enxergar"" os conflitos obscuros dos pacientes, tem a intenção de quebrar o princípio de Tirésias no qual reza: o homem só seria capaz de ver à mercê de uma cegueira. Todo o esforço do futuro psicanalista, em sua análise didática, é no sentido de "curar-se de suas cegueiras", de sua falta de "insight", e chegar a ter, cada vez menos, "escotomas". É como muito bem afirma Rof Carballo "que somente à mercê de nossa cegueira podemos alcançar a visão total e profunda sobre a realidade". Rascovsky refere-se à glândula pineal como o olho externo dos animais inferiores que se transformou em olho interno, na evolução da escala zoológica, com o fito de melhor visão interna e assim englobar uma visão total e satisfatória.

O drama de Édipo não é, pois, só “complexo de Édipo", representa mais uma complexa realidade do grupo familiar, cujos pais concorrem, inconscientemente, para a problemática conflitiva do filho.

$\mathrm{O}$ indivíduo sofre a influência dos pais não somente na vida exterior (de fora), sentindo-a como contundente, mas, também, no parto (trauma do nascimento de Rank) e na vida intra-uterina, pois, segundo Abadi, o feto percebe, embora não recorde, como quer Rascovsky, a angústia materna, o que se pode constatar pela maior movimentação e taquicardia fetal. A maior angústia de fora levaria o indivíduo à ansiedade persecutória própria dos esquizofrênicos; a maior angústia de dentro, à claustrofobia, especial dos neuróticos obsessivos e nos estados de ansiedade. O desejo inconsciente de voltar ao útero materno é por timidez diante da luta pela vida e se manifesta de maneira somática pela astenia, síndrome hipometabólica. Nesta situação há um desejo de reconciliação com a mãe, para ser protegido e aplacada a culpa, mas o medo de ser rejeitado é tão grande que entre o mal maior, participar da cena primária (figura combinada perseguidora) podendo ser castrado, prefere o mal menor (astenia, fobia etc.) e assim, "cultivando" a neurose, procura participar da vida, embora em "angústia existencial". A psicanálise faz reviver estas condições "de dentro e de fora" em cada sessão. Ao ser psicanalisado, como ao nascer, o indivíduo se converte na hamlética verbalização da dúvida: "ser no útero ou ser fora", como no sentimento clássico: "ser ou não ser". No Édipo, a angústia fetal é por ter sido gerado por mãe rechaçante, a Esfinge-Jocasta; angústia do nascimento a perplexidade de Édipo frente ao abandono e à rejeição, e a angústia pós-natal é Édipo frente à realidade da vida movida por mecanismos inconscientes, culpando o destino.

Édipo representaria, pois, uma predestinação por fatôres inconscientes, uma reação da fuga diante da mãe agressiva e diante de um pai homossexual; ambos com medo do próprio filho, motivado pela Lei de Talião; seria, portanto, o resultado de erros de educação produzidos por conflitos inconscientes da mãe e do pai.

\section{Nelson Poci ${ }^{459}$}

Só com muita sabedoria poderia transmitir todo o conteúdo dessa peça, como eu o senti. Sendo meus conhecimentos limitados ao campo da medicina e da psicanálise, vou-me contentar em dar este conteúdo dentro destes aspectos.

\footnotetext{
${ }^{459}$ Instituto de Psicanálise da Sociedade Brasileira de Psicanálise de São Paulo.
} 
Primeiramente, peço licença de discordar de Flávio Rangel. Édipo ao contrário do que foi afirmado, sofre do "complexo de Édipo". O fato de que ele tenha matado o pai e casado com a mãe, isto é, de ter vivido este complexo, não quer dizer que ele não o tenha.

Justifico o meu ponto de vista nos seguintes aspectos:

1. A grande angústia que sentiu quando tomou conhecimento da profecia, em Delfos, ao verificar se era ou não filho legítimo de Pólibo.

2. As resistências que enfrentou para conhecer a verdade, quando do diálogo com Tirésias.

3. A angústia deste momento vivido através daquele grito profundamente dramático que soltou, quando leva as mãos aos órgãos genitais, indo até à castração, único meio de poder ter vida interior livre.

4. Finalmente, quando castrado, pôde pedir a presença das filhas, senti-las e acariciálas, porque não estava mais sujo, tinha-se despojado, através da cegueira, do falo, que não sabia manejar, isto é: "complexo de Édipo".

Comentaria ainda que o desencadeante da tragédia foi o fato de Édipo ter atingido a idade de Laio, quando morreu, e de ter filhos com a idade que ele, Édipo, tinha quando matou Laio. Grande parte da honestidade pesquisadora de Édipo deve-se ao medo inconsciente de que a mesma coisa acontecesse com ele próprio. Aliás, existe entre outros um trabalho de Josephine Hilgart, "Aniversary Symptom”, citado por Mário Carlisky, que mostra, baseado em rico material clínico, a tendência à rememorízação, pelos filhos, de traumas sofridos pelos pais, quando atingem a idade em que os pais sofreram aqueles traumas.

Finalmente, queria também chamar a atenção que nem sempre o destino do complexo de Édipo é a tragédia; cada um escolhe o seu caminho: Goethe, por exemplo, faz Fausto tornar-se eternamente jovem. Isto abre os nossos horizontes, deixando a linha trágica para Sófocles. Neste ponto, a psicanálise é o nosso grande apoio, porque ela nos oferece as bases para a compreensão, vivência e integração destes aspectos na nossa rotina diária.

\section{Richard Kanner ${ }^{460}$}

Gostaria de iniciar dizendo, em primeiro lugar, que não me parece caber o receio expresso pelo ator Paulo Autran de que a arte se empobreça quando colocada debaixo do prisma psicanalítico. A minha opinião é que quando arte e ciência se juntam, cada uma respeitando os limites próprios e portanto alheios, ambas saem enriquecidas técnica e filosoficamente. Não sinto que os analistas que me precederam tenham tido a intenção de querer reduzir essa peça a uma situação, na qual toda a pujança artística da mesma ficaria subordinada à compreensão psicanalítica.

Chamo a atenção dos presentes para um aspecto psicológico que se encontra muito em grupos humanos e está bem patente em Édipo rei. Embora desde o início se procure um culpado para o assassínio do rei Laio, há um momento em que Édipo pergunta o que tinha acontecido para que ninguém tivesse tomado uma providência na ocasião da eliminação do rei. Essa frágil tentativa de estabelecer a verdade, no sentido de mostrar a culpa coletiva, sucumbe logo em seguida quando se restabelece o clima da procura do criminoso único.

Vemos que aqui aparece claramente o fenômeno, conhecido por todos, do bode expiatório. Negada a culpa de todos, "alguém" tinha que pagar. Este processo está combinado, conforme vemos na peça, com a Lei do Talião, combinação essa que contribui fundamentalmente para a eclosão da tragédia final, que se compõe de suicídio, automutilação, difamação pública e outras vinganças.

Essa combinação típica do Superego arcaico pode ser observada em funcionamento constante nos mecanismos psicológicos grupais. Temos na época atual um típico exemplo

\footnotetext{
${ }^{460}$ Instituto de Psicanálise da Sociedade Brasileira de Psicanálise de São Paulo.
} 
desta situação em matéria de política internacional. Em conversa com um amigo, este me chamou a atenção para o fato de que dois líderes dos blocos que estão sempre em choque, isto é, o ocidental e o oriental, se sentam para buscar um entendimento que elimine os atritos ou pelo menos os suavize. Estamos falando de Kennedy e Krutchev. Em pouco tempo os dois são apeados do poder e vemos reconduzidos à liderança homens que se acusam mutuamente e se prometem vinganças. A constelação primitiva se refez. Parece que neste sentido estamos repetindo sem variação a movimentação psicológica coletiva assinalada em Édipo rei.

Para finalizar esta pequena observação, não poderia deixar de cumprimentar os atores pelo seu desempenho brilhante, que acredito ter emocionado a todos nós. Muito obrigado.

\section{Edú Machado Gomes ${ }^{461}$}

Dentro do pensamento fenomenológico existencial, podemos condensar a análise de Édipo rei nas seguintes proposições: Sófocles.

1. A verdade de Édipo não é a dele, que é apenas um personagem, mas, sim, a de

2. Sófocles apela para a comoção sentimental a fim de atingir a comunicação com o público, principalmente de sua época e de seu povo.

3. A análise desta comoção revela uma exasperação do patético como única saída do homem sem futuro, predestinado, sem possibilidade de modificar o seu destino.

4. A conclusão é a de que todas as vezes que se predestina um homem, tira-se dele o seu futuro. A existência sobressai como um tempo fatal a ser cumprido inexoravelmente e não como um tempo a ser vivido e criado. No meu entender Édipo rei não chega a ser uma tragédia no sentido verdadeiro e grandioso da dramaturgia, porque lhe falta o conflito fundamental do ser em liberdade, do antagonismo entre o dionisíaco e o apolíneo. $\mathrm{O}$ personagem mítico grego, no qual se inspirou Sófocles e mais tarde Freud, traduz bem o espanto e perplexidade do homem diante de sua vida instintiva em conflito com uma moral que em seu projeto essencial impele o homem para uma organização social, feita à custa da repressão não só do instinto sexual, como também de outros instintos.

A situação de Édipo pode ser vista historicamente na evolução da psicologia humana como um mecanismo original de repressão, para transformar-se com a descoberta de Freud num mecanismo de regressão inconsciente.

Existencialmente toda regressão significa volta ao passado, por falta de futuro, que na análise existencial, nem sempre ele, o futuro, está bloqueado por incapacidade individual, mas na maioria das vezes por ser apenas reflexo das totalidades sociais, que massificam e objetivam o homem.

Édipo rei é um exemplo disto: originalmente ele é um enigmista, isto é, um homem que descobre enigmas através da razão. Sua sociedade é vítima de uma epidemia. Sua razão esgota-se na impossibilidade de enquadramento racional do problema. Surgem os deuses com a exigência do sacrifício expiatório. Édipo volta-se a si mesmo. Predestina-se e é predestinado. Expia ele próprio toda culpa, entregando num gesto de grandeza humana todo o poder de novo ao povo, quando ele não mais teve solução para seus problemas, quando teve, por exemplo, que derrotar a esfinge. Parece claro que para os gregos todo poder encerra culpa, porque ora ele é furtado aos deuses, ora ele é furtado aos homens. Daí a expiação necessária aos poderosos quando todos estão ameaçados. A sociedade redime-se e o alívio é geral, com nova mobilização de energias.

Édipo rei é a culpa de todo seu povo. Seu sacrifício torna-se necessário e ele mesmo o compreende. O patético surge porque ele também sabe que a solução verdadeira não devia ser esta. Seu urro de misericórdia e desespero ressoa através dos séculos.

\footnotetext{
${ }^{461}$ Médico psiquiatra do Departamento de Assistência aos psicopatas.
} 